\title{
UJI AKTIVITAS ANTIOKSIDAN EKSTRAK KULIT BATANG DALU-DALU (Salix tetrasperma Roxb) MENGGUNAKAN METODE DPPH (1,1-DIFENIL-2-PIKRILHIDRAZIL)
}

\author{
Syafrinal $^{(1)}$, Sari Ramadhani ${ }^{(2)}$ \\ ${ }^{(1)}$ Analisis Kimia, Politeknik ATI Padang \\ ${ }^{(2)}$ Kimia, Universitas Andalas \\ rinal1450@gmail.com
}

\begin{abstract}
Abstrak
Penelitian ini bertujuan untuk mengetahui aktivitas antioksidan dari ekstrak kulit batang Dalu - Dalu (Salix tetrasperma Roxb) dengan menggunakan metode DPPH (1,1-difenil-2-pikrilhidrazil). Ekstraksi dilakukan dengan metode maserasi menggunakan n-heksana, etil asetat dan metanol. Aktivitas antioksidan diukur menggunakan spektrofotometer UV-Vis dan dinyatakan sebagai nilai IC50. Hasil pengukuran secara spektrofotometri menunjukkan bahwa fraksi n-heksana memiliki aktivitas antioksidan yang sangat lemah dengan nilai IC50 sebesar 713,58 ppm, fraksi etil asetat dan metanol memiliki aktivitas antioksidan yang sangat kuat dengan nilai IC50 sebesar $9,14 \mathrm{ppm}$ dan $12,68 \mathrm{ppm}$ serta asam askorbat sebagai kontrol positif memiliki aktivitas antioksidan sangat kuat dengan IC50 sebesar 10,65 ppm.
\end{abstract}

Kata Kunci : aktivitas antioksidan, kulit batang Dalu - Dalu, metode DPPH.

\section{PENDAHULUAN}

Radikal bebas adalah suatu molekul yang mempunyai elektron yang tidak berpasangan. Elektron yang tidak berpasangan tersebut menyebabkan rasikal bebas yang sangat reaktif yang kemudian akan menangkap atau mengambil elektron dari senyawa lain seperti proteon, lipid, karbohidrat dan DNA untuk menetralkan diri. Radikal bebas dapat masuk ke dalam tubuh dan menyerang sel-sel yang sehat dan menyebabkan sel-sel tersebut kehilangan fungsi dan strukturnya. Akumulasi dari kerusakan tersebut berkontibusi terhadap beberapa penyakit dan menyebabkan kondisi yang biasa disebut penuaan dini (Liochev, 2013).

Radikal bebas dapat ditangkal oleh antioksidan. Antioksidan berdasarkan sumbernya dapat dibedakan menjadi antioksidan sintetik dan alami. Adanya kekhawatiran terhadap efek samping antioksidan sintetik berupa hepatomegali, mempengaruhi aktivitas enzim di hati serta karsinogenik, menyebabkan antioksidan alami menjadi alternatif yang terpilih (Sunarni, dkk. 2007).

Dalu-dalu (Salix tetrasperma Roxb.) adalah salah satu tumbuhan yang digunakan sebagai bahan obat tradisional yang umum dikenal dengan Indian Willow (Kiritikar KR and Basu BD, 2005). Pemeriksaan profil fitokimia ekstrak kulit batang dalu-dalu mengungkapkan adanya steroid, sterol, triterpen, tanin, senyawa fenolik, saponin dan flavonoid (Raj, Chhetree R. et al. 2010). 
Senyawa antioksidan alami tanaman umumnya adalah senyawa fenolik atau polifenolik yang dapat berupa golongan flavonoid, bioflavonoid, vitamin $\mathrm{C}$, tokoferol, $\beta$-karoten, katekin, resveratrol, turunan asam sinamat, kumarin, dan asam-asam organik polifungsional. Kelompok flavonoid utama adalah flavanol, flavanon, isoflavon, katekin, proantosianidin dan antosianin. Sementara turunan asam sinamat meliputi asam kafeat, asam ferulat, asam klorogenat, dan lain-lain.

Metode yang digunakan untuk mengidentifikasi aktifitas antioksidan salah satunya adalah DPPH (1,1-difenil 2-pikrilhidrazil). DPPH merupakan radikal bebas yang apabila direkasikan dengan ektrak tanaman yang mengandung antioksidan, maka akan terjadi reaksi penaangkapan radikal bebas DPPH yang diubah menjadi 1,1 difenil 2-pikrilhidrazin (kuning) (Yen dan Chen, 1995). Keuntungan metode DPPH adalah metode yang sederhana, cepat dan mudah diukur absorbansinya dengan spektrofotometer Uv - Vis pada panjang gelombang $517 \mathrm{~nm}$ (Kurniawan, 2013).

Penentuan aktivitas antioksidan menggunakan asam askorbat sebagai pembanding . Selain itu, parameter lain yang digunakan untuk mengetahui kekuatan antioksidan ialah $\mathrm{IC}_{50}$ (inhibition Concentration 50 Value). $\mathrm{IC}_{50}$ merupakan konsentrasi yang dapat menghambat aktivitas radikal bebas DPPH sebanyak $50 \%$. Semakin kecil $\mathrm{IC}_{50}$ menandakan semakin besar aktivitas antioksidan (Molyneux, 2004). Setiap ektrak dengan pelarut yang berbeda akan memiliki kandungan senyawa yang bermacam-macam serta berpengaruh terhadap besarnya aktivitas penangkapan radikal bebas.

\section{METODE PENELITIAN}

\section{Bahan}

Bahan yang digunakan untuk uji fitokimia hingga uji antioksidan adalah kloroform (Brataco), akuades, besi(III) klorida (Merck), anhidrida asetat (Fisson), amonia (Merck), pereaksi Liebermann-Burchard (asam sulfat pekat dan anhidrida asetat), $\mathrm{NaOH}$, metanol (Merck), etil asetat (Merck), n-heksana (Merck), 1,1-difenil-2-pikrilhidrazil (DPPH) dan asam askorbat.

\section{Alat}

Alat yang digunakan adalah peralatan gelas yang umum digunakan di laboratorium, alat destilasi, alat rotary evaporator (Betracher Lamag $^{\circledR}$ ), spektrofotometer UV-Vis (Shimadzu ${ }^{\circledR}$ UV 1700).

\section{Metode Penelitian}

\section{Prosedur Penelitian}

1. Pengambilan dan persiapan sampel

Sampel yang diperlukan untuk penelitian ini diperoleh dari Sianik Sago, Kec. IV Jurai, Kab. Pesisir Selatan. Sebanyak $13 \mathrm{~kg}$ sampel segar kulit batang dalu-dalu dikering anginkan sehingga diperoleh $6 \mathrm{~kg}$ kulit batang Dalu-dalu kering, dibersihkan, dipotong kecil-kecil, kemudian di haluskan menggunakan alat grinder sehingga berbentuk serbuk halus.

2. Pembuatan larutan 1,1-difenil-2pikrilhidrazil (DPPH)

Sebanyak 1,97 mg DPPH dilarutkan dengan metanol dalam labu ukur sampai $100 \mathrm{~mL}$ sehingga diperoleh larutan dengan konsentrasi $50 \mu \mathrm{M}$. 


\section{Uji fitokimia}

Sampel sebanyak 2 gram dipotong halus dan dimasukan ke dalam tabung reaksi, kemudian dimaserasi dengan metanol yang telah dipanaskan (di atas penangas air) selama 15 menit. Kemudian disaring panas panas ke dalam tabung reaksi lain dan biarkan seluruh metanol menguap hingga kering. Lalu ditambahkan kloroform dan akuades dengan perbandingan 1:1 masing masingnya sebanyak $5 \mathrm{~mL}$, kocok dengan baik, kemudian pindahkan ke dalam tabung reaksi, biarkan sejenak hingga terbentuk dua lapisan kloroform-air. Lapisan kloroform di bagian bawah digunakan untuk pemeriksaan senyawa triterpenoid dan steroid. Lapisan air digunakan untuk pemeriksaan senyawa flavonoid, fenolik, dan saponin.

\subsection{Pemeriksaan (Sianidin Tes) \\ Flavonoid}

Sebagian dari lapisan air diambil dan dipindahkan dengan menggunakan pipet ke dalam tabung reaksi, kemudian tambahkan asam klorida pekat dan beberapa butir bubuk magnesium, terbentuknya warna jingga sampai merah menunjukkan adanya flavonoid (kecuali untuk flavon).

\subsection{Pemeriksaan Fenolik}

Sebagian dari lapisan air diambil dan dipindahkan dengan pipet ke dalam tabung reaksi kecil, kemudian tambahkan pereaksi besi (III) klorida, terbentuknya warna biru/ungu menandakan adanya senyawa fenolik.

\subsection{Pemeriksaan Saponin}

Dari lapisan air, kocok kuat-kuat dalam sebuah tabung reaksi, terbentuknya busa yang tidak hilang dengan penambahan beberapa tetes asam klorida pekat menunjukkan adanya saponin.

\subsection{Pemeriksaan Triterpenoid dan Steroid (Liebermann-Burchard)}

Dari lapisan kloroform diambil sedikit dan dimasukkan ke dalam dua lubang plat tetes, biarkan hingga kering. Ke dalam satu lubang plat tetes ditambahkan asam sulfat pekat, ke dalam lubang plat tetes lainnya ditambahkan setetes anhidrida asetat dan setetes asam sulfat pekat. Terbentuknya warna hijau atau hijau biru menandakan adanya steroid, sedangkan bila terbentuknya warna merah atau merah ungu menandakan adanya triterpenoid.

\subsection{Pemeriksaan Alkaloid.}

Sampel sebanyak 2-4 gram dipotong kecil-kecil, kemudian dihaluskan dalam lumpang dengan penambahan sedikit pasir dan $10 \mathrm{~mL}$ kloroformamoniak $0,05 \mathrm{~N}$, kemudian diaduk dan digerus perlahan. Larutan disaring dengan corong kecil, di dalamnya diletakkan kapas sebagai penyaring dan hasil saringan dimasukkan ke dalam sebuahtabung reaksi, kemudian tambah kan 10 tetes asam sulfat $\mathrm{N}$ dan kocok secara perlahan. Biarkan sejenak sampai terbentuk pemisahan lapisan asam dan kloroform. Lapisan asam diambil dengan bantuan pipet dan dipindahkan ke dalam sebuah tabung reaksi kecil. Kemudian tambahkan pereaksi Meyer, reaksi positif ditandai dengan adanya endapan putih $(+4)$, kabut putih tebal $(+3)$, kabut putih tipis (+2), kabut putih sangat tipis $(+1)$.

\subsection{Pemeriksaan Kumarin}

Sampel sebanyak 2-5 gram dirajang halus dan diekstrak dengan pelarut metanol. Hasil ekstrak ditotolkan 
pada batas bawah plat KLT dengan menggunakan pipa kapiler, dibiarkan kering pada udara terbuka. Kemudian dielusi dalam bejana yang berisi 10 $\mathrm{mL}$ eluen etil asetat $100 \%$. Noda yang dihasilkan dimonitor di bawah lampu UV (365 nm). Hasil KLT kemudian disemprot dengan larutan natrium hidroksida $1 \%$ dalam etanol : air (1:1) dan selanjutnya dilihat dibawah lampu UV (365 nm). Adanya fluorisensi yang bertambah terang setelah disemprot dengan larutan natrium hidroksida $1 \%$ menandakan adanya senyawa kumarin.

\section{Ekstraksi}

Ekstraksi sampel kulit batang Daludalu dilakukan dengan metoda maserasi. $6 \mathrm{~kg}$ serbuk halus kulit batang Dalu-dalu dimasukkan ke botol gelap,dimaserasi dengan pelarut n-heksana selama 3 hari.Proses maserasi diulangi dengan pelarut yang sama hingga hasil perendaman tersebut menjadi bening. Sampel disaring sehingga diperoleh filtrat dan ampas.Filtrat n-heksana yang dihasilkan tersebut dipekatkan dengan rotary evaporator pada suhu $40^{\circ}$ Csehingga didapatkan ekstrak pekat $n$-heksana. Ampas yang tersisa dimaserasi dengan pelarut etil asetat (enam kali perendaman) dan pelarut metanol (enam kali perendaman). Hasil maserasi dipekatkan dengan rotary evaporatorpada suhu $40^{\circ} \mathrm{C}$ sehingga diperoleh ekstrak pekat etil asetat dan ekstrak pekat metanol.ekstrak kental dilakukan uji fitokimia dan uji antioksidan.
5. Metode Pengujian Aktivitas Antioksidan

Penentuan absorban dari larutan DPPH dilakukan dengan dipipet $4 \mathrm{~mL}$ larutan 1,1-difenil-2-pikrilhidrazil 50 $\mu \mathrm{M}$ dan ditambahkan $1 \mathrm{~mL}$ metanol. Setelah dibiarkan 30 menit ditempat gelap, diukur serapannya alat dengan spektrofotometer UV-Vis pada panjang gelombang $517 \mathrm{~nm}$, absorban yang diperoleh digunakan sebagai kontrol.

Pemeriksaan aktivitas antioksidan, dilakukan dengan menimbang ekstrak sebanyak 2,5 mg dan larutkan dengan metanol dalam labu ukur $25 \mathrm{~mL}$ sampai tanda batas, sehingga diperoleh konsentrasi sampel 100 ppm lalu diencerkan menjadi konsentrasi 40, 20, 10 dan 5 ppm. Kemudian untuk penentuan aktivitas antioksidan dipipet sebanyak $1 \mathrm{~mL}$ larutan sampel dengan pipet mikro dan masukkan kedalam botol vial, kemudian ditambahkan $4 \mathrm{~mL}$ larutan 1,1-difenil-2-pikrilhidrazil $50 \mu \mathrm{M}$. Campuran dihomogenkan dan dibiarkan selama 30 menit ditempat gelap, serapan diukur dengan spektrofotometer UV-Vis pada panjang gelombang $517 \mathrm{~nm}$.

Aktivitas antioksidan sampel ditentukan oleh besarnya hambatan serapan radikal bebas melalui perhitungan persentase inhibisi serapan 1,1-difenil-2 pikrilhidrazil dengan menggunakan rumus :

$\%$ Inhibisi $=\underline{\text { Absorban kontrol }- \text { Absorban sampel }} \times 100 \%$ Absorban kontrol 


\section{HASIL DAN PEMBAHASAN}

\section{Uji Fitokimia}

Hasil fitokimia dari kulit batang Dalu dalu dapat dilihat pada Tabel 1 . Dari data pada Tabel 1 dapat diketahui bahwa kulit batang Dalu-dalu mengandung senyawa flavonoid, fenolik, terpenoid, saponin dan steroid.

Masing-masing ekstrak (ekstrak metanol, etil asetat dan n-heksana) kulit batang Dalu-dalu dilakukan uji fitokimia untuk melihat senyawa apa saja yang terkandung di dalam masing-masing ekstrak. Hasil uji profil fitokimia dapat dilihat pada Tabel 2.
Tabel 1. Hasil Uji Fitokimia pada Kulit Batang Dalu-dalu

\begin{tabular}{|c|c|c|c|}
\hline $\begin{array}{l}\mathrm{N} \\
\mathrm{O}\end{array}$ & $\begin{array}{l}\text { Kandungan } \\
\text { kimia }\end{array}$ & $\begin{array}{l}\text { Reagent/ } \\
\text { pereaksi }\end{array}$ & Hasil \\
\hline 1. & Alkaloid & Mayer & - \\
\hline 2. & Flavonoid & Sianidin test & + \\
\hline 3. & Fenolik & $\begin{array}{l}\text { Besi (III) } \\
\text { klorida 5\% }\end{array}$ & + \\
\hline 4. & Terpenoid & $\begin{array}{l}\text { Liebermann } \\
\text {-Burchard }\end{array}$ & + \\
\hline 5. & Saponin & Aquadest & + \\
\hline 6. & Steroid & $\begin{array}{l}\text { Liebermann } \\
\text {-Burchard } \\
\text { Natrium }\end{array}$ & + \\
\hline 7 & Kumarin & $\begin{array}{c}\text { Hidrokisda } \\
10 \%\end{array}$ & - \\
\hline
\end{tabular}

Keterangan; (+) berarti terdeteksi.

Tabel 2. Hasil Uji Fitokimia Ektrak Kulit Batang Dalu-Dalu

\begin{tabular}{|c|c|c|c|c|c|}
\hline No & $\begin{array}{c}\text { Kandungan } \\
\text { kimia }\end{array}$ & $\begin{array}{l}\text { Reagent/ } \\
\text { pereaksi }\end{array}$ & $\begin{array}{c}\text { Ekstrak } \\
\text { n heksana }\end{array}$ & $\begin{array}{c}\text { Ekstrak } \\
\text { Etil Asetat }\end{array}$ & $\begin{array}{l}\text { Ekstrak } \\
\text { Metanol }\end{array}$ \\
\hline 1. & Alkaloid & Mayer & - & - & - \\
\hline 2. & Flavonoid & Sianidin test & - & + & + \\
\hline 3. & Fenolik & $\begin{array}{l}\text { Besi (III) } \\
\text { klorida 5\% }\end{array}$ & + & + & + \\
\hline 4. & Terpenoid & $\begin{array}{l}\text { Liebermann } \\
\text {-Burchard }\end{array}$ & + & + & + \\
\hline 5. & Saponin & Aquadest & + & + & + \\
\hline 6. & Steroid & $\begin{array}{l}\text { Liebermann } \\
\text {-Burchard } \\
\text { Natrium }\end{array}$ & + & + & + \\
\hline 7 & Kumarin & $\begin{array}{l}\text { Hidrokisda } \\
10 \%\end{array}$ & - & - & - \\
\hline
\end{tabular}

Dari hasil fitokimia, senyawa yang paling dominan yang terdapat di ketiga ekstrak adalah senyawa fenolik, flavonoid, steroid, triterpenoid dan saponin sedangkan alkaloid dan kumarin tidak teridentifikasi pada masingmasing ekstrak.

\section{Uji Antioksidan}

Pada pengujian awal uji antioksidan ini ditentukan terlebih dulu panjang gelombang maksimum DPPH. Dari hasil pengukuran didapatkan panjang gelombang DPPH $\lambda$ maks adalah 517 nm. Panjang gelombang ini digunakan untuk pengukuran absorban larutan sampel. Dari $4 \mathrm{~mL}$ DPPH $50 \mu \mathrm{M}$ yang ditambahkan dalam $1 \mathrm{~mL}$ metanol digunakan sebagai kontrol didapatkan absorban sebesar 0,4128.

Parameter yang umum digunakan untuk mengetahui aktivitas antioksidan adalah dengan menentukan nilai inhibition concentration $50 \%$ (IC). Nilai IC dari ektrak heksana, etil asetat dan metanol dari kulit batang Dalu-Dalu 
(Salix tetrasperma Roxb) serta asam askorbat sebagai pembanding dapat dilihat pada Tabel 3.

Tabel 3. Tabel Nilai IC $_{50}$ Ekstak kulit Batang Dalu-Dalu dan Asam Askorbat

\begin{tabular}{|c|c|c|}
\hline Ekstrak & $\begin{array}{c}\text { Persamaan } \\
\text { Grafik }\end{array}$ & $\begin{array}{l}{\text { Nilai } \mathrm{IC}_{50}}_{(\mathrm{ppm})}\end{array}$ \\
\hline n-Heksana & $\begin{array}{l}y=0,0706 x \\
-0,3793 \\
R^{2}=0,9664\end{array}$ & 713,58 \\
\hline Etil Asetat & $\begin{array}{l}y=3,1246 x \\
+21,44 \\
R^{2}=0,9389\end{array}$ & 9,14 \\
\hline Metanol & $\begin{array}{l}y=4,2287 x \\
-3,625 \\
R^{2}=0,9726\end{array}$ & 12,68 \\
\hline $\begin{array}{l}\text { Asam } \\
\text { Askorbat }\end{array}$ & $\begin{array}{l}y=3,6111 x \\
+11,54 \\
R^{2}=1\end{array}$ & 10,65 \\
\hline
\end{tabular}

Berdasarkan hasil yang didapatkan pada Tabel 3, menunjukkan bahwa nilai $\mathrm{IC}_{50}$ ektrak etil asetat < asam askorbat $<$ ektrak etanol < ektrak n-heksana, bila semakin kecil nilai $\mathrm{IC}_{50}$ maka aktivitas antioksidan semakin tinggi (Molyneux. 2004), yang berarti . aktivitas antioksidan ektrak etil asetat > asam askorbat > ektrak etanol > ektrak nheksana. Hal ini diduga karena Ekstak etil asetat kulit batang Dalu-Dalu melarutkan senyawa-senyawa baik dari yang polar sampai yang kurang polar, sehingga senyawa-senyawa yang aktif antioksidan banyak terekstrak pada pelarut ini. Sedangkan ektrak n-heksana hanya mengekstrak senyawa-senyawa yang bersifat non polar saja.

Kategori aktivitas antioksidan suatu senyawa dapat digolongkan berdasarkan Tabel 4 (Andriani dkk, 2015).
Tabel 4. Penggolongan Aktivitas Antioksidan Berdasarkan Nilai $\mathrm{IC}_{50}$

\begin{tabular}{|l|l|}
\hline Nilai $\mathrm{IC}_{50}$ & Kategori \\
\hline$<50 \mathrm{ppm}$ & Sangat Kuat \\
\hline $50 \mathrm{ppm}-100 \mathrm{ppm}$ & Kuat \\
\hline $100 \mathrm{ppm}-150 \mathrm{ppm}$ & Sedang \\
\hline $150 \mathrm{ppm}-200 \mathrm{ppm}$ & Lemah \\
\hline$>200 \mathrm{ppm}$ & Sangat Lemah \\
\hline
\end{tabular}

Dari Tabel 4 menunjukan bahwa ektrak etil asetat dengan nilai $\mathrm{IC}_{50} 9,14$ ppm dan ektrak etanol dengan nilai $\mathrm{IC}_{50}$ 12,68 ppm dikategorikan sebagai antioksidan yang sangat kuat seperti asam askorbat yang dijadikan sebagai pembanding dengan nilai $\mathrm{IC}_{50} \quad 10,65$ ppm sedangkan ektrak n-heksana sebagai antioksidan yang sangat lemah dengan nilai $\mathrm{IC}_{50} 713,58 \mathrm{ppm}$

\section{KESIMPULAN}

Dari hasil uji fitokimia diketahui kulit batang Dalu-Dalu mengandung senyawa metabolit sekunder diantaranya flavonoid, fenolik, terpenoid, saponin dan steroid. Pada uji antioksidan nilai $\mathrm{IC}_{50}$ terbesar terdapat pada ekstrak etil asetat yaitu 9,14 ppm dan ektrak metanol 12,68 ppm yang menandakan bahwa kedua ekstrak ini memiliki aktivitas antioksidan yang sangat kuat sedangkan ektrak n-heksana mempunyai aktivitas antioksidan yang sangat lemah dengan nilai $\mathrm{IC}_{50} 713,58 \mathrm{ppm}$.

\section{DAFTAR PUSTAKA}

Andriani, Y. N.M. Ramli, D.F. Syamsumir, M.N.I. Kassim, J. Jaafar, N.A. Aziz, L. Marlina, N.S. Musa, H. Mohamad,, 2015, Phytochemical Analysis, Antioxidant, Anti bacterial and Cytotoxicity Properties Of Keys and Cores Parts Of Pandanus 
tectorius Fruits, Arabian Journal of Chemistry.

Kiritikar KR and Basu BD. 2005. Indian medicinal plants. Deharadun, India, Lalit Mohan Basu. 23622363.

Kurniawan J.C, Suryanto Edi, dan Yudistira A. 2013.Analisis Fitokimia dan Uji aktivitas Antioksidan dari Getah Kulit Buah Pisang Goroho (Musa acuminate $L)$ Jurnah Ilmiah Farmasi. UNSRAT Vol 2 No 3.

Liochev, S.I. 2013.Reactive Oxygeb Species and the free Radical Theory of Aging. free Radical Biology and Medicine.60. 1-4

Molyneux. 2004. The Use of The Stable Free Radical Diphenyl picrylhydrazyl (DPPH ) for Estimating Antioxidant Activity.
Songklanakarin Journal Science Technology . Vol 26 (2): 211- 219.

Raj, Chhetree R., Dash GK, Mondal S AndParhi R. 2010. Studies On The Hypoglycaemic Activity of The Bark Salix Tetrasperma Roxburgh. International Journal of Drug Development \& Research. Covered in Official Product of Elsevier, The Netherlands Vol. 2 Issue 4 ISSN 0975-9344.

Sunarni, T., Pramono, S., dan Asmah, R. 2007. Flavonoid Antioksidan Penangkap Radikal dari Daun Kepel (Stelechocarpus burahol (B1. Hook f. \& Th).Majalah Informasi Indonesia 18 (3) : 111- 116

Yen, G.C. dan Chen. H.Y. 1995.Antioxidant Activity of Variaous Tea Extract In Relation to Their Antimutagenicity.J.Agric. Food. Chem. 